July, Aug. Sept., 1952

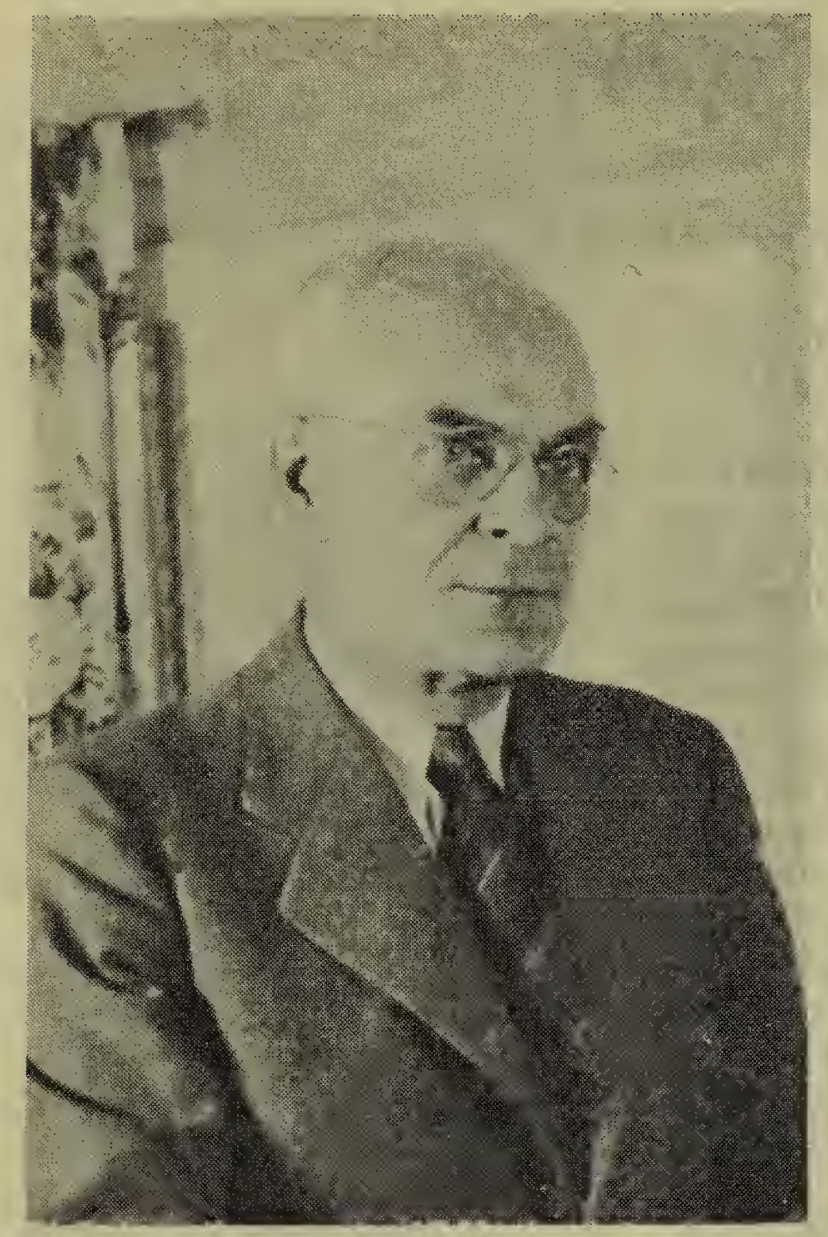

"After thirty odd years of bird watching in a small town of northeastern Saskatchewan, what are your inost pleasant and vivid memories?" Mr. Editor, you ask difficult guestions.

The most pleasant memories and satisfactions come from the helping hand given to beginners. It has been a pleasure to watch one generation after another acquiring a fascinating and wholesome nobby. Several have far exceeded their teacher in skill and tenacity. I am honoured to count among my bird children none other than Maurice G. Street, who is Bird Editor of The Blue Jay and who has done such good work with bird banding and with the bird census of his district.

The most vivid memories come from those birds which I have seen in this district on rare occasions only. The Lewis's Woodpecker was a find. It was observed on November 2lst, 1925. The identification was verfied by none other than the principal of Tisdale High School; L.T. Carmichael, present Editor of The Blue Jay. A pair of Bobolinks was seen in a meadow north of Valparaiso on June 23rd, 1929, a

\section{Thirty Happy Years}

\author{
E. W. Van Blaricom, Q.C.
}

pair of Western Tanagers on July $4 \mathrm{th}$, 1940, and a Spotted Towhee on May 3 lst, 1945. The Blackbilled Cuckoo came and went with the army worm attacking the poplars. The date was July lst, 1948. The latest addition to single observations was the Philadelphia Vireo observed on July 10, 1948. As Columbus could never forget America, so the birdwatcher can never forget his new discoveries.

During these thirty years species of birds have come and gone. My first magpie was a curiosity. It had been caught in a trapline, a trapline and brought into me for identification on December 1lth, $1923 . \quad$ Today Magpies can be seen in any trip in any direction, My first Baltimore Oriole was observed on June 4th, 1929. Now these charming birds nest yearly in our Doghide Valley. The first Hoary Redpoll was seen by my wife and bird companion on March 5th, 1930. It resulted in words of doubt and a much delayed dinner until identification had been verified (by me). Now these winter friends are quite ocmmon.

There's the reverse side of the picture. The Bald Eagle is only a memory. The Yellow-headed Blackbird is hard to find. Mountain Bluebirds. visit us each spring but, finding no place to nest, pass on. Man with his bulldozer has had his effect upon the continuty of bird life in the district.

The older I grow the more I am convinced that no out-of-doors amusement, will better repay a busy man than the study of the birds that live around him. I am certain the author of "The Birds of Brewery Creek" would agree while J.J. Hickey in his "Guide to Bird Watching" makes use of an expression I have copied into each of my bird books. In closing I pass it along to each and all of you:"To the ornithologist no corner of the earth is dull, no season without its compensations." 